\title{
EKSPLORASI GEOARKEOLOGI SITUS PALEOLITIK DI PULAU SERAM, PROVINSI MALUKU \\ (Geoarchaeological Exploration of Paleolitical Sites on The Island of Seram, Moluccas Province)
}

\author{
Muh. Fadhlan S. Intan \\ Pusat Penelitian Arkeologi Nasional. JI. Raya Condet Pejaten No. 4 Jakarta Selatan 12510, e-mail: \\ geobugis@yahoo.co.id
}

\section{INFO ARTIKEL}

\section{Histori artikel}

Diterima: 31 Maret 2017

Direvisi: 3 Mei 2017

Disetujui:12 Juni 2017

\section{Keywords:}

geology,

pleistocene,

paleolithic,

open site,

lithic tools materials

\section{Kata kunci:}

geologi,

Plistosen

Paleolitik,

situs terbuka,

bahan alat litik

\begin{abstract}
East Seram District, Central Maluku, and West Seram regency is located on the island of Seram, where research was conducted, save a lot of cultural, one of the paleolithic period, which is a long time not received attention from environmental researchers. It is used as the basis of the main issues that include geology in general. Therefore, the purpose of this study was to perform surface geological mapping in general as one of the efforts to provide geological information, while the goal is to determine aspects of geomorphology, stratigraphy, structural geology associated with the existence of paleolithic sites in the study area. The research method begins with a literature review, surveys, analysis, and interpretation of field data. Environmental scanning provides information about the landscape consists of plains morphological units, units of corrugated morphology weak, strong corrugated morphology unit, and units of karst morphology. The river berstadia old-mature river stadium, periodical/permanent river, and river episodic/intermittent river. Constituent rock is sandstone, limestone, marl, andesite, tuff, schist, volcanic breccias, reef limestones, conglomerates, and alluvial. Geological structures such as faults and folds. Ceram Research discovered 14 Paleolithic sites. From the analysis of petrology, lithic tools made of jasper rocks, chert, metalimestone, flint, and quartzite. Rock as raw material litik tool, found in the middle of Seram Island, then spread to the west and to the east which has a flat relief.
\end{abstract}

\begin{abstract}
ABSTRAK
Kabupaten Seram Bagian Timur, Kabupaten Maluku Tengah, dan Kabupaten Seram Bagian Barat terletak di Pulau Seram, yang menjadi lokasi penelitian, menyimpan banyak tinggalan budaya, salah satunya dari masa paleolitik, yang sekian lama tak mendapat perhatian dari para peneliti lingkungan. Hal inilah yang dijadikan dasar permasalahan utama yang mencakup geologi secara umum. Oleh sebab itu, maksud penelitian ini dalah untuk melakukan pemetaan geologi permukaan secara umum sebagai salah satu upaya untuk menyajikan informasi geologi, sedangkan tujuannya adalah untuk mengetahui aspek-aspek geomorfologi, stratigrafi, struktur geologi yang dikaitkan dengan keberadaan di situs-situs paleolitik wilayah penelitian. Metode penelitian diawali dengan kajian pustaka, survei, analisis, dan interpretasi data lapangan. Pengamatan lingkungan memberikan informasi tentang bentang alamnya terdiri yang dari satuan morfologi dataran, satuan morfologi bergelombang lemah, satuan morfologi bergelombang kuat, dan satuan morfologi karst. Sungainya berstadia sungai dewasa-tua, sungai periodik/permanen, dan sungai episodik/ intermittent. Batuan penyusun adalah batupasir, batugamping, napal, andesit, tufa, sekis, breksi volkanik, batugamping terumbu, konglomerat, dan aluvial. Struktur geologi berupa patahan, dan lipatan. Eksplorasi di Pulau Seram telah menemukan 14 situs paleolitik. Dari analisis petrologi, alat-alat litik terbuat dari batuan jasper, chert, metagamping, batuapi, dan kuarsit. Batuan sebagai bahan baku alat litik, ditemukan di bagian tengah Pulau Seram, lalu disebarkan ke arah barat dan timur yang berelief datar.
\end{abstract}




\section{PENDAHULUAN}

Maluku adalah sebuah provinsi di Indonesia, dengan ibukotanya adalah Ambon. Provinsi Maluku terdiri atas gugusan kepulauan yang dikenal dengan Kepulauan Maluku. Wilayah Kepulauan Maluku terletak pada posisi $2^{\circ} 30^{\prime}-9^{\circ}$ lintang selatan dan $124^{\circ}-135^{\circ}$ bujur timur (BPS, 2015). Kepulauan Maluku, secara geografis terletak di antara Provinsi Maluku Utara, Papua Barat, Sulawesi Tenggara dan Sulawesi Tengah, Negara Timor Leste dan Australia. Provinsi Maluku dibatasi oleh Provinsi Maluku Utara di sebelah utara; Provinsi Papua Barat di sebelah timur; Provinsi Sulawesi Tenggara dan Sulawesi Tengah di sebelah barat; serta dengan Negara Timor Leste dan Australia di sebelah selatan.

Secara topografis, sebagai akibat bentuk kepulauan yang terdiri dari gunung-gunung dan pulau-pulau, yang memanjang dari barat ke timur, dari utara ke selatan sepanjang 1150 $\mathrm{km}$, dengan luas daratan $85.728 \mathrm{~km}^{2}$ atau 8.572.800 ha memiliki bentuk lahan dataran seluas 1.251.630 ha $(14,6 \%)$, berombak seluas 2.417 .530 ha $(28,2 \%)$ dan bukit dan pegunungan seluas 4.903 .640 ha $(57,2 \%)$. Provinsi Maluku merupakan daerah kepulauan yang terdiri dari 559 pulau dan dari sejumlah pulau tersebut, terdapat beberapa pulau yang tergolong pulau besar. Daratan Provinsi Maluku tidak terlepas dari gugusan gunung dan danau yang terdapat hampir di seluruh kabupaten/kota, yang berjumlah empat gunung dan sebelas danau. Adapun gunung yang tertinggi yaitu Gunung Binaya dengan ketinggian $3.055 \mathrm{~m}$ terletak di Pulau Seram, Kabupaten Maluku Tengah (BPS, 2015).

Kepulauan Maluku beriklim tropis dan iklim Muzon dimana iklim ini sangat dipengaruhi oleh lautan yang luas. Temperatur rata-rata dari tiga stasiun BMG adalah $27^{\circ} \mathrm{C}$, dengan curah hujan sebesar 184,13 mm (BPS, 2015).

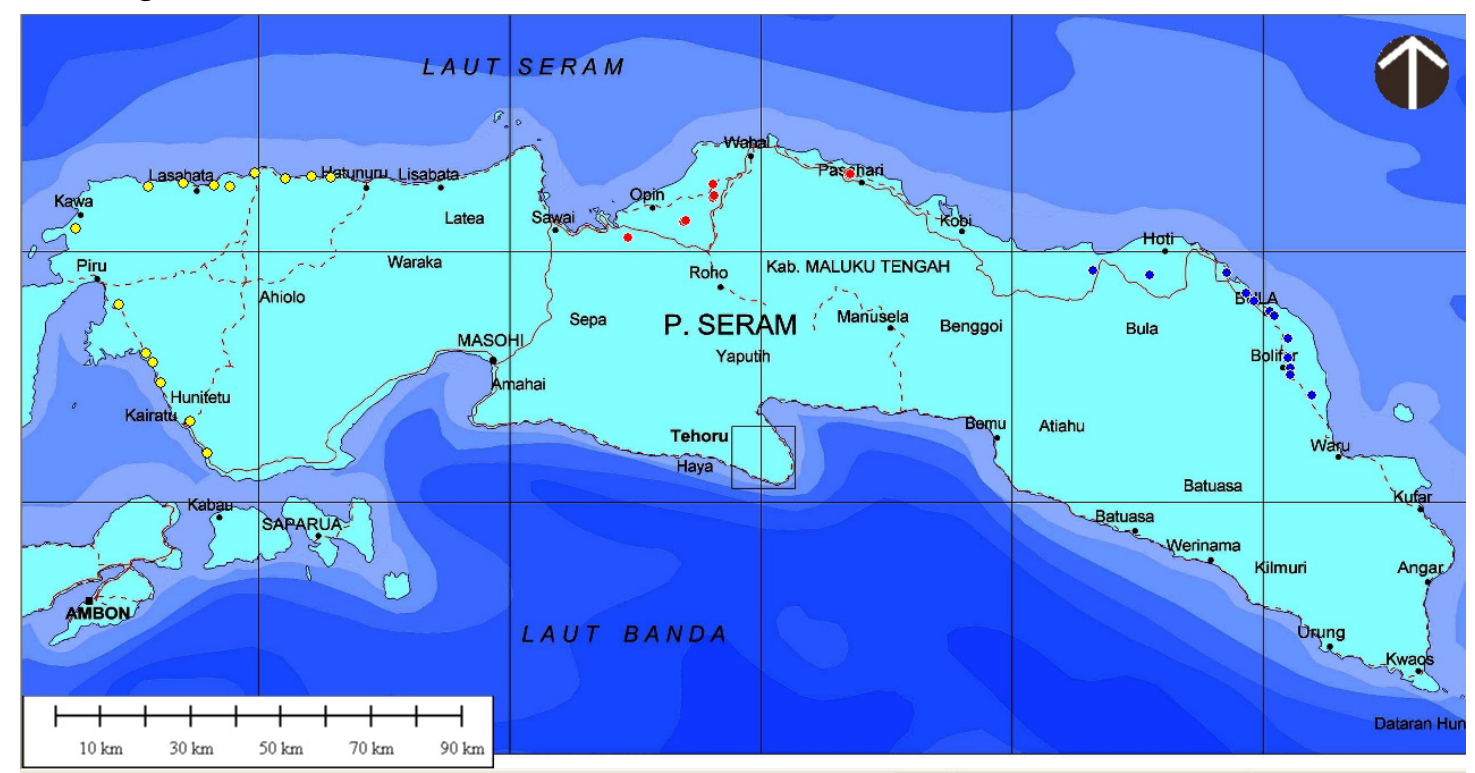

Peta 1. Pulau Seram dan lokasi pengamatan (sumber: Kusuma dkk., 2012 dengan pengolahan) 
Pulau Seram yang luasnya 1,86 juta hektar, terletak di sebelah utara Pulau Ambon. Pulau Seram memiliki alam pegunungan dan hutan tropis yang eksotis dan unik. Salah satu kekayaan Pulau Seram adalah kawasan batugamping (limestone) yang telah mengalami proses-proses alamiah dalam batasan ruang dan waktu geologi.

Informasi tentang keberadaan temuan alat-alat paleolitik di wilayah ujung timur Kepulauan Indonesia (terutama di sekitar wilayah Maluku, Seram, Halmahera dan Papua), diinformasikan oleh Hadiwisastra (1999) yang menyatakan bahwa di wilayah Seram Tengah bagian utara (Kecamatan Sawai) ditemukan alatalat paleolitik (sebanyak lima buah) yang terbuat dari bahan kalsedon hitam, marmer dan silisifikasi tuff (Hadiwisastra, 1999: 85-90), dan ditindaklanjuti oleh Puslit Arkenas melalui Eksplorasi Sumberdaya Budaya Paleolitik di Pulau Seram Bagian Utara, Provinsi Maluku pada tahun 2012.

\section{Batasan masalah dalam} penelitian ini, mengkaji lingkup bagian utara dari Pulau Seram. Rumusan masalah dalam penelitian ini adalah: a) bagaimana kondisi bentang alam daerah telitian (satuan geomorfik, pola dan stadia sungai)?; b) bagaimana stratigrafi daerah telitian (kontak antar satuan batuan)? dan; c) bagaimana permasalahan struktur geologi daerah telitian (struktur geologi apa saja yang mengontrol daerah telitian)?. Maksud dari penelitian ini adalah untuk melakukan pemetaan geologi permukaan secara umum sebagai salah satu upaya untuk menyajikan informasi geologi yang ada, serta melakukan suatu analisa berdasar atas data pada daerah telitian, kemudian dibuat suatu laporan penelitian untuk melengkapi penelitian di Pulau Seram. Tujuan penelitian yaitu untuk mengetahui kondisi geologi yang meliputi aspek geomorfologi, stratigrafi, struktur geologi, dalam konteks sumber bahan alat-alat litik.

Penelitian di Pulau Seram dilaksanakan di Kabupaten Seram Bagian Timur, Kab. Seram Bagian Barat, dan Kabupaten Maluku Tengah. Lokasi penelitian tercantum pada Peta Rupa Bumi Indonesia Lembar 2613 (Taniwel), Lembar 2712 (Werinama), dan Lembar 2713 (Wahai), berskala 1:250.000.

\section{Metode}

Metode penelitian yang digunakan dalam penelitian ini, dilakukan dengan beberapa tahap, yang diawali dengan:

Kajian Pustaka, dilakukan dengan mempelajari lokasi penelitian dari peneliti terdahulu, buku, jurnal, maupun dari internet. Survei, dilakukan dengan mengamati keadaan geomorfologinya yang mencakup bentuk bentang alam, dan bentuk sungai. Kemudian lithologi yang mencakup jenis batuan, batas 
penyebaran batuan, dan uruturutan pengendapan. Selanjutnya struktur geologi yang terdapat di wilayah penelitian, misalnya patahan (fault), lipatan (fold) dan kekar (joint) melalui pengukuran jurus (strike) dan kemiringan (dip). Selama survei akan dilakukan pengambilan sampel batuan yang akan digunakan dalam analisa laboratoris.

Analisis, hasil pengamatan lapangan akan di analisis lebih lanjut di laboratorium maupun dalam bentuk pembuatan peta (misalnya peta geologi, peta geomorfologi). Langkah analisis akan disesuaikan dengan kebutuhan dan urutan kerja geologi, yaitu:

a. Lithologi, sampel batuan dianalisis, melalui petrologi, unsur batuan yang dianalisis adalah jenis batuan, warna, kandungan mineral, tekstur, struktur, fragmen, matriks, semen. Hasil analisis akan memberikan produk nama batuan.

b. Geomorfologi,

penentuan bentuk bentang alam akan mempergunakan Sistem Desaunettes (1977), (Todd 1980), yang didasarkan atas besarnya kemiringan lereng dan beda tinggi relief suatu tempat. Hasilnya adalah pembagian wilayah berdasarkan ketinggian dalam bentuk prosentase lereng. Pengamatan sungai dilakukan untuk melihat pola pengeringan (drainage basin), misalnya klasifikasi berdasarkan atas kuantitas air, pola dan stadia sungai.

c. Struktur Geologi: Pengamatan struktur geologi di lapangan akan dilanjutkan melalui analisis jenis struktur, misalnya patahan (fault) apakah jenis patahan normal (normal fault), patahan naik (thrust fault), patahan geser (strike fault) dan sebagainya. Lipatan (fold) apakah sinklin ataukah antiklin. Kekar (joint) apakah kekar tiang (columnar joint) atau kekar lembar (sheet joint).

Data-data dari kajian pustaka dengan hasil lapangan dan laboratorium dikompilasikan dengan hasil penelitian penulis, dan langkah terakhir dilakukan interpretasi peta geologi dan peta topografi.

\section{HASIL DAN PEMBAHASAN}

Nama Maluku pertama kali digunakan oleh bangsa Portugis untuk menyebutkan pulau-pulau yang terletak diantara Sulawesi dan Papua. Yang termasuk pulau-pulau itu adalah Halmahera, Ternate, Tidore, Obi Sula, Seram, Buru, Ambon dan Banda. Dalam tulisan ini, Maluku dipakai dalam arti yang luas, yaitu meliputi seluruh kompleks dari kelompok dan rangkaian pulau yang batas-batasnya adalah sebagai berikut: di sebelah utara dengan kepulauan Filipina, di sebelah timur dengan Papua, di sebelah tenggara benua Australia, sebelah baratdaya pulau-pulau Sunda Kecil dan di sebelah barat dengan Sulawesi Bemmelen (1949). Kepulauan Maluku 
terdiri dari \pm 9000 pulau, yang terbagi dalam lima kelompok kepulauan, yaitu Kepulauan Halmahera, Seram, Kai, Aru, dan Tanimbar.

Geologi Regional Seram, dikemukakan pertama kali oleh Kemp dan Mogg (1992:521-551), Kemp (1992, 11.1-33), Kemp, Mogg, dan Barraclough (1995). Berdasarkan kenampakan geomorfologi, Pulau Seram membentang dari timur-barat $\pm 340 \mathrm{~km}$ dan utara-Sselatan $\pm 70 \mathrm{~km}$. Mempunyai pegunungan dengan hutan yang rapat, titik tertinggi di Pulau Seram adalah 3.027 mdpl. Kemiringan lereng berkisar antara $30-60 \%$ dari Gunung Markele sampai Gunung Binaya yang merupakan titik tertinggi tersebut. Sebagian besar kawasan ini memiliki kelerengan yang terjal dan lembah-lembah yang dalam. Bagian yang landai terletak dibagian utara Wahai dan Sasarata serta bagian selatan di daerah Hatumete dan Woke. Pulau Seram mempunyai potensi sumberdaya air dan lahan yang cukup tinggi. Potensi air permukaan cukup besar dengan teramatinya volume air yang besar pada sungai-sungai di sekitar Teluk Elpaputih, Teluk Taluti, dan sekitar Wahai. Potensi air tanah sangat besar di sepanjang pantai utara daerah Seram Timur antara Nief dan Wahai. Hampir semua sungai yang mengalir ke utara kehilangan volume airnya karena meresap kedalam batuan yang sangat lulus air (batupasir dan konglomerat) (Jatmiko, dkk., 2012).

\section{Geologi Wilayah Pulau Seram}

Pengamatan

lingkungan

geologi pada penelitian ini mencakup aspek bentuk bentang alam, batuan penyusun, dan struktur geologi di wilayah Pulau Seram dan sekitarnya.

\section{Geomorfologi}

Morfologi atau bentuk bentang alam dipengaruhi oleh beberapa faktor yaitu: a) lithologi; b) struktur; c) stadia daerah dan; d) tingkat perkembangan erosi (Thornbury, 1964). Berdasarkan hal tersebut diatas, bentang alam (morfologi) di wilayah Pulau Seram sekitarnya, secara umum memperlihatkan kondisi dataran bergelombang. Kondisi bentang alam seperti ini, apabila di klasifikasikan dengan mempergunakan Sistem Desaunettes, 1977 (Todd 1980), yang berdasarkan atas besarnya prosentase kemiringan lereng dan beda tinggi relief suatu tempat, maka wilayah Pulau Seram terbagi atas empat satuan satuan morfologi yaitu:

a) Satuan Morfologi Dataran, dengan prosentase kemiringan lereng antara $0-2 \%$; b) Satuan Morfologi Bergelombang Lemah, dengan prosentase kemiringan lereng antara 2-8\%. c) Satuan Morfologi Bergelombang Kuat, dengan prosentase kemiringan lereng antara 8-16\% dan; d) Satuan Morfologi Bergelombang Karst. Secara umum ketinggian wilayah penelitian 7-45 meter diatas permukaan air laut. 


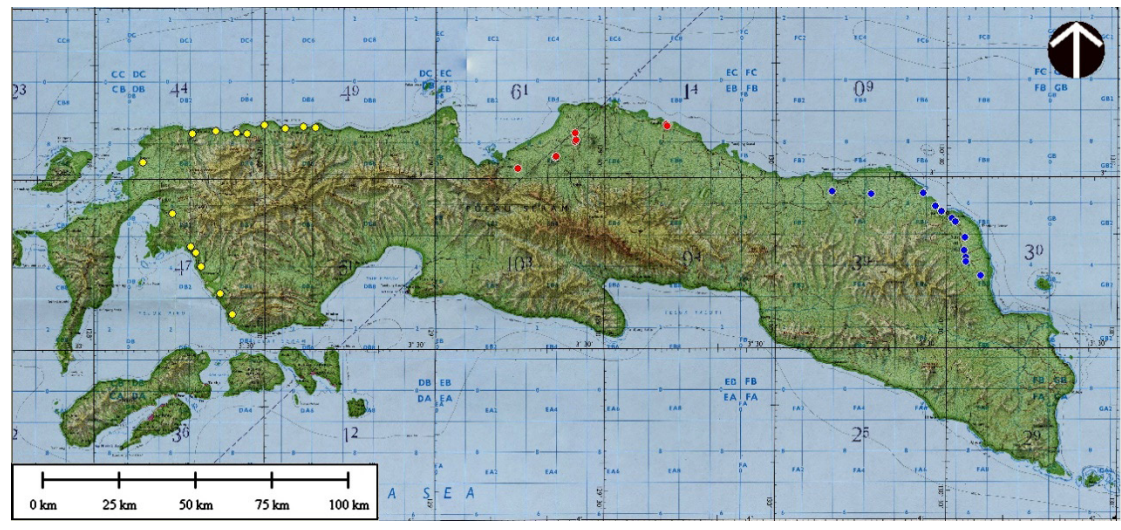

Peta 2. Pulau Seram Provinsi Maluku dan lokasi pengamatan dalam Peta Topografi (sumber: Army Service Map1968, Sheet 52 Ambon, Series 1301, Edition 3-AMS Word-Asia, dengan pengolahan)

Pola aliran permukaan (surface drainage pattern) sungai-sungai ke arah utara dan mengikuti bentuk bentang alam lokasi penelitian. Sungaisungai yang mengalir di Kabupaten Maluku Tengah (Pulau Seram) adalah Wai Salawai, Wai Sapalewa, Wai Wahatu, Wai Putih-Putih, Wai Kua, Wai Isal, Wai Yala, Wai Ela, dan Wai Mitiu. Di Kabupaten Seram Bagian Timur adalah Wai Matakabo, Wai Bobi, Wai Pupa, Wai Lola Besar, Wai Lola Kecil, Wai Kalimati, Wai Bulaair, Wai Balipar, Wai Salas, Wai Kola, Wai Nif, Wai Mer. Sedangkan sungai di Kabupaten Seram Bagian Barat adalah Wai Kaputih, Wai Jali, Wai Teha, Wai Hanoli, Wai Kalipana, Wai Kalisama, Wai Hanua, Wai Pana, Wai Kawa, Wai Eti, Wai Aru, Wai Kamal, Wai Kawaninu, Wai Wapa, dan Wai Selopai.

\section{Sungai-sungai tersebut}

termasuk pada kelompok sungai yang berstadia sungai dewasa-tua (oldmature river stadium) dan sungai tua (old stadium) (Lobeck, 1939; Thornbury, 1964). Klasifikasi berdasarkan kuantitas air, maka sungai-sungai di wilayah penelitian termasuk termasuk pada sungai periodik/permanen dan sungai episodik/intermittent (Lobeck, 1939; Thornbury, 1964).

\section{Stratigrafi}

Stratigrafi regional Pulau Seram, tersusun atas satuan batuan dari yang tua ke muda adalah sebagai berikut; a); Batuan Ultramafik (Jku), Serpentinit, Gabro; b) Komplek Taunusa (Pzta) terdiri dari sekis, kuarsit, genes, amfibolit, pualam dan filit; c) Komplek Tehuru (PTrt) terdiri dari filit, batusabak, batugamping terpualamkan dan sedikit sekis; d) Komplek Saku (Trs) terdiri dari Batu sabak, grewake meta dan konglomerat meta dengan sisipan gamping; e) Formasi Kanikeh (TrJk) terdiri dari perselingan batu pasir, serpih dan lanau, dengan sisipan konglomerat dan batu gamping; f) Formasi Manusela (TrJm) terdiri dari batu gamping mengandung koral, kalsilutit dan batu gamping oolit; g) Komplek Uli (Tmpu) disusun oleh berbagai jenis batuan berukuran dari beberapa centimeter tercampur 
di dalam massa dasar lempung; $h$ ) Formasi Sawai (KS) terdiri dari kalsilutit, serpih merah dan rijang mengandung radiolaria; i) Formasi Hatuolo (Tpeh) terdiri dari serpih pasiran, napal, rijang; j) Formasi Lisabata terdiri dari Formasi Fufa (TQf) disusun oleh perselingan batu gamping, batu pasir, batu lanau dan lempung di bagian bawah, batu pasir dan konglomerat di bagian atas; k) Batuan Konglomerat (Qt) terdiri dari aneka bahan batuan Batuan gamping terumbu (QI) diperkirakan berumur Plistosen Atas sampai Holosen dan; I) Batuan endapan permukaan - aluvium (Qa).

Satuan batuan yang menyusun wilayah penelitian di Pulau Seram dan sekitarnya, didasarkan atas ciri lithologi, dan posisi stratigrafi. Berdasarkan hal tersebut, maka batuan yang menyusun wilayah penelitian adalah batu pasir, batu gamping, napal, andesit, tufa, sekis, breksi volkanik, batu gamping terumbu, konglomerat, dan aluvial.

Hasil analisis petrologi dari batuan-batuan tersebut adalah sebagai berikut:

a. Aluvial (alluvial), terdiri dari pasir, lanau, dan lempung serta merupakan hasil pelapukan batuan penyusun wilayah penelitian (Huang, 1962). Satuan batuan ini terhampar di satuan morfologi datararan, di tepi pantai, dan di pinggir-pinggir sungai, serta berumur Holosen (Tjokrosapoetro dkk, 1993a; Tjokrosapoetro dkk, 1993b; Gafoer dkk., 1993).

b. Konglomerat (conglomerate), termasuk pada batuan sedimen mekanik (Huang, 1962). Batuan ini dapat disebandingkan dengan Konglomerat (Qt) yang berumur Plistosen-Holosen (Tjokrosapoetro dkk, 1993a; Tjokrosapoetro dkk, 1993b; Gafoer dkk., 1993).

c. Batugamping Terumbu (reeflimestone), termasuk dalam jenis batuan sedimen organik (Huang, 1962). Batuan ini dapat disebandingkan dengan Batugamping Koral (QI) yang diperkirakan berumur Plistosen Atas - Holosen (Tjokrosapoetro dkk, 1993a; Tjokrosapoetro dkk, 1993b; Gafoer dkk., 1993).

d. Breksi Volkanik (Volcanic Breccia), termasuk pada batuan sedimen volkanik(pyroclastic)(Huang, 1962).

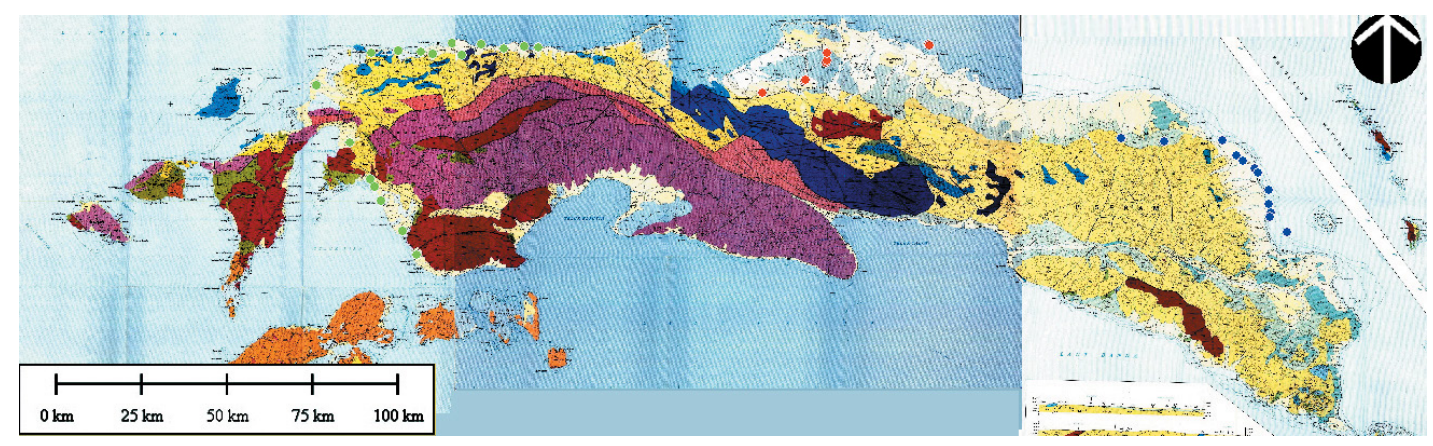

Peta 3. Geologi Pulau Seram dan lokasi pengamatan (sumber: (Tjokrosapoetro dkk, 1993a; Tjokrosapoetro dkk, 1993b; Gafoer dkk., 1993 dengan pengolahan) 
Batuan ini dapat disebandingkan dengan Batuan Gunungapi Ambon (Tpav) yang berumur berumur Pliosen (Tjokrosapoetro dkk, 1993a; Tjokrosapoetro dkk, 1993b; Gafoer dkk., 1993).

e. Sekis (schist), termasuk termasuk pada batuan metamorf foliasi (Huang, 1962). Batuan ini dapat disebandingkan dengan Kompleks Uli (Tmpu) yang berumur Miosen Akhir (Tjokrosapoetro dkk, 1993a; Tjokrosapoetro dkk, 1993b; Gafoer dkk., 1993).

f. Tufa (tuff), termasuk pada batuan sedimen volkanik (pyroclastic) (Huang, 1962). Batuan ini dapat disebandingkan dengan Batuan Gunungapi Kelang (Tmkv) yang berumur Miosen Akhir (Tjokrosapoetro dkk, 1993a; Tjokrosapoetro dkk, 1993b; Gafoer dkk., 1993).

g. Andesit (andesite), termasuk pada batuan beku intermediate (Huang, 1962). Batuan ini dapat disebandingkan dengan Batuan Gunungapi Kelang (Tmkv) yang diperkirakan berumur Miosen Akhir (Tjokrosapoetro dkk, 1993a; Tjokrosapoetro dkk, 1993b; Gafoer dkk., 1993).

h. Napal (marl), termasuk pada batuan sedimen mekanik (epyclastic) (Huang, 1962). Batuan ini dapat disebandingkan dengan Formasi Lisa Bata (Toml) yang berumur Oligosen Akhir - Miosen Tengah (Tjokrosapoetro dkk, 1993a;
Tjokrosapoetro dkk, 1993b; Gafoer dkk., 1993).

i. Batugamping (limestone), termasuk pada batuan sedimen karbonat (Huang, 1962). Batuan ini dapat disebandingkan dengan Formasi Manusela (TrJm) yang berumur Trias Akhir - Jura (Tjokrosapoetro dkk, 1993a; Tjokrosapoetro dkk, 1993b; Gafoer dkk., 1993).

j. Batupasir (sandstone), termasuk pada batuan sedimen mekanik (epyclastic) (Huang, 1962). Batuan ini dapat disebandingkan dengan Formasi Kanikeh (Trjk) yang berumur Trias Akhir - Jura (Tjokrosapoetro dkk, 1993a; Tjokrosapoetro dkk, 1993b; Gafoer dkk., 1993).

\section{Struktur Geologi}

Pulau Seram terletak sepanjang utara busur Banda, Indonesia bagian timur. Pulau Seram berada pada zona tektonik kompleks, karena Pulau Seram merupakan pertemuan tiga lempeng tektonik, yaitu: Lempeng Australia, Lempeng Pasifik-Filipina, dan Lempeng Eurasia. Pulau Seram dan Ambon adalah bagian dari Busur Banda. Data stratigrafi menunjukkan bahwa perkembangan tektonik kedua pulau itu, dari Paleozoik sampai Miosen, sangat erat dengan perkembangan tektonik tepi benua Australia. Interaksi konvergen antara lempeng Eurasia, Indo-Australia dan Pasifik pada Miosen Akhir yang diikuti oleh rotasi Kepala Burung berlawanan 
arah jarum jam pada Mio-Pliosen telah menyebabkan perkembangan tektonik kedua kawasan itu berbeda, sehingga unit litologi dari Pulau Seram dan Ambon dapat dibedakan menjadi Seri Australia dan Seri Seram. Data stratigrafi menunjukkan bahwa paling kurang terjadi dua kali kompresi tektonik dan dua kali continental break up berkait dengan pembentukan Pulau Seram dan Ambon.

Pulau Seram dicirikan oleh pola struktur dan stratigrafi yang rumit. Pulau ini, seperti halnya Pulau Timor berada pada bagian Busur Luar Banda yang merupakan Busur non-vulkanik. berdasarkan penelitian regional oleh beberapa peneliti, disebutkan bahwa Geologi Pulau Seram merupakan mirror image dari Pulau Timor. Kelompok batuan sedimen tertua di Pulau Seram adalah Formasi Kanikeh dan Formasi Manusela (Tjokrosapoetro dkk, 1993a; Tjokrosapoetro dkk, 1993b; Gafoer dkk., 1993).

Struktur geologi yang melewati wilayah penelitian dan sekitarnya adalah patahan (fault) dan lipatan (fold). Patahan (fault) dari jenis sesar naik (thrust fault), dan sesar geser (strike slip fault), sedangkan lipatan (fold) dari jenis antiklin (anticline) (Billing, 1972). Pada umumnya, sesar naik dan sumbu antiklin

Peta 4. Pulau Seram dan lokasi pengamatan (diolah dengan menggunakan perangkat lunak Global Mapper V.11 - 2009; data topografi berdasarkan Jarvis et. al. 2008) yang berarah barat laut-tenggara mengindikasikan bahwa deformasi pada daerah ini dipengaruhi oleh kompresi yang berarah timur lautbarat daya. Kenampakan singkapan yang memperlihatkan sesar naik ini didominasi di bagian tengah dan bagian timur dari Pulau Seram. Sesar utama dan pengangkatan di Pulau Seram diawali pada Miosen Akhir-Pliosen Awal. Kemudian sejak terjadinya proses tersebut, Pulau Seram secara tektonik selalu aktif. Ini diindikasikan dengan adanya pengangkatan dan erosi dari sedimen Plio-Pleistosen dari bagian tengah pulau serta adanya proses sesar mendatar mengiri yang sangat kuat. Bukti di lapangan dari keberadaan sesar mendatar ini adalah adanya perubahan arah aliran sungai yang dikendalikan oleh sesar mendatar dan adanya offset dari batuan yang ada.

\section{Situs Paleolitik Pulau Seram}

Penelitian di Pulau Seram dilakukan di tiga kabupaten (Kabupaten Maluku Tengah, Kabupaten Seram Bagian Timur, dan Kabupaten Seram Bagian Barat), berhasil menemukan 32 lokasi situs paleolitik, sebagai berikut: 
Tabel 1. Lokasi Penelitian di Kabupaten Maluku Tengah, Provinsi Maluku

\begin{tabular}{|c|c|c|c|}
\hline No & Lokasi & Koordinat & Ketinggian (mdpl) \\
\hline \multirow[t]{2}{*}{1} & $\begin{array}{l}\text { Wai Sapalewa, Desa Roho, Kec. Seram } \\
\text { Utara, Kab. Maluku Tengah }\end{array}$ & $\begin{array}{l}02^{\circ} 56^{\prime} 29,3^{\prime \prime} \text { LS } \\
129^{\circ} 20^{\prime} 50,8^{\prime \prime} \text { BT }\end{array}$ & 26 \\
\hline & $\begin{array}{l}\text { Wai Sapalewa, Desa Roho, Kec. Seram } \\
\text { Utara, Kab. Maluku Tengah }\end{array}$ & $\begin{array}{l}02^{\circ} 56^{\prime} 21,6^{\prime \prime} \mathrm{LS} \\
129^{\circ} 2101,7^{\prime \prime} \mathrm{BT}\end{array}$ & 29 \\
\hline \multirow[t]{2}{*}{2} & $\begin{array}{l}\text { Wai Putih-Putih, Dusun Uhela, Desa } \\
\text { Roho, Kec. Seram Utara, Kab. Maluku } \\
\text { Tengah }\end{array}$ & $\begin{array}{l}02^{\circ} 53^{\prime} 38,5^{\prime \prime} \mathrm{LS} \\
129^{\circ} 2419,4^{\prime \prime} \mathrm{BT}\end{array}$ & 45 \\
\hline & $\begin{array}{l}\text { Wai Putih-Putih II, Desa Roho, Kec. } \\
\text { Seram Utara, Kab. Maluku Tengah }\end{array}$ & $\begin{array}{l}02^{\circ} 53^{\prime} 19,8^{\prime \prime} \text { LS } \\
129^{\circ} 24^{\prime} 30,8^{\prime \prime B T}\end{array}$ & 34 \\
\hline 3 & $\begin{array}{l}\text { Wai Kua, Desa Roho, Kec. Seram Utara, } \\
\text { Kab. Maluku Tengah }\end{array}$ & $\begin{array}{l}02^{\circ} 52^{\prime} 05,1 ” \mathrm{LS} \\
129^{\circ} 24^{\prime} 21,7 \mathrm{BT}\end{array}$ & 24 \\
\hline \multirow[t]{2}{*}{4} & $\begin{array}{l}\text { Wai Isal, Desa Siatele, Kec. Seram Utara, } \\
\text { Kab. Maluku Tengah }\end{array}$ & $\begin{array}{l}02^{\circ} 50^{\prime} 40,9^{\prime \prime} \mathrm{LS} \\
129^{\circ} 40^{\prime} 31,1 " \mathrm{BT}\end{array}$ & 10 \\
\hline & $\begin{array}{l}\text { Wai Isal, Desa Siatele, Kec. Seram Utara, } \\
\text { Kab. Maluku Tengah }\end{array}$ & $\begin{array}{l}02^{\circ} 50^{\prime} 51,5^{\prime \prime} \mathrm{LS} \\
129^{\circ} 40^{\prime} 40,1^{\prime \prime B T}\end{array}$ & 14 \\
\hline 5 & $\begin{array}{l}\text { Wai Salawai, Desa Sawai, Kec. Seram } \\
\text { Utara, Kab. Maluku Tengah }\end{array}$ & $\begin{array}{l}02^{\circ} 58^{\prime} 22,1 \text { 'LS } \\
129^{\circ} 14^{\prime} 14,0 \text { "B BT }\end{array}$ & 7 \\
\hline
\end{tabular}

Kabupaten Maluku Tengah

Berdasarkan data arkeologis yang berhasil dikumpulkan, di Kabupaten Maluku Tengah, diperoleh lima situs paleolitik yang menunjukkan adanya indikasi aktivitas manusia masa lalu, sebagai berikut:

\section{Situs Paleolitik Sungai Sapalewa}

Situs Paleolitik Sungai Sapalewa termasuk wilayah Desa Roho, Kecamatan Seram Utara, Kabupaten Maluku Tengah. Pengamatan di Sungai Sapalewa dilakukan pada dua titik pengamatan, yaitu titik pengamatan 1 dan titik pengamatan 2, dengan jarak 412 meter dengan arah timur laut $\left(\mathrm{N} 55^{\circ} \mathrm{E}\right)$. Lokasi pengamatan-1 terletak pada koordinat $02^{\circ} 56^{\prime} 29.3$ Lintang Selatan dan 129'20'50,8" Bujur Timur dengan ketinggian 26 meter diatas permukaan air laut (dpl), dan lokasi pengamatan 2 terletak pada koordinat $02^{\circ} 56^{\prime} 21.6^{\prime \prime}$ Lintang Selatan dan 129²1'01,7" Bujur Timur dengan ketinggian 29 meter diatas permukaan air laut (dpl).

Hasil pengamatan permukaan yang dilakukan di kedua lokasi ini, telah menemukan alat-alat litik berupa serpih (flakes), batu inti (core) dan bahan baku alat litik. Bahan batuan untuk alat-alat litik tersebut adalah jasper, chert, kuarsit, batuapi, dan metagamping (Jatmiko, dkk., 2012).

\section{Situs Paleolitik Sungai Wai Putih- Putih}

Situs Paleolitik Sungai Wai Putih-Putih, termasuk wilayah Dusun Uhala, Desa Roho, Kecamatan Seram Utara, Kabupaten Maluku Tengah. Pengamatan di Wai Putih-Putih dilakukan pada dua titik pengamatan, 
yaitu titik pengamatan 1 dan titik pengamatan 2 , dengan jarak 798 meter dengan arah timur laut $\left(\mathrm{N} 32^{\circ} \mathrm{E}\right)$. Lokasi pengamatan 1 terletak pada koordinat $02^{\circ} 53^{\prime} 38,5^{\prime \prime}$ Lintang Selatan dan 129'24'19,4" Bujur Timur dengan ketinggian 45 meter diatas permukaan air laut (dpl), dan lokasi pengamatan 2 terletak pada koordinat $02^{\circ} 53^{\prime} 19,8^{\prime \prime}$ Lintang Selatan dan $129^{\circ} 24^{\prime} 30,8^{\prime \prime}$ Bujur Timur dengan ketinggian 34 meter diatas permukaan air laut ( $\mathrm{m} \mathrm{dpl}$ ).

Hasil pengamatan permukaan yang dilakukan di kedua lokasi ini, telah menemukan alat-alat litik berupa kapak penetak (chopping-tools), kapak perimbas (chopper), serpih (flakes), batu inti (cores) dan serpih dengan retus (retouched flakes) dengan kategori serut samping, serut gerigi, serut cekung dan serut berpunggung. Bahan batuan untuk alat-alat litik tersebut adalah jasper, chert, kuarsit, batuapi, dan metagamping (Jatmiko, dkk., 2012).

\section{Situs Paleolitik Sungai Wai Kua}

Situs Paleolitik Sungai Wai Kua, termasuk wilayah Desa Roho, Kecamatan Seram Utara, Kabupaten Maluku Tengah. Secara geografis titik pengamatan di Sungai Wai Kua berada pada koordinat $02^{\circ} 52^{\prime} 05,1^{\prime \prime}$ Lintang Selatan dan $129^{\circ} 24^{\prime} 21,7^{\prime \prime}$ Bujur Timur dengan ketinggian $24 \mathrm{~m}$ dpl.

Hasil pengamatan permukaan yang dilakukan di lokasi ini, telah menemukan alat-alat litik berupa serpih (flakes), batu inti (core) dan serpih dengan retus (retouched flakes) dengan kategori serut ujung, serut gerigi, serut cekung, serut samping, bilah (pisau) dan lancipan. Bahan batuan untuk alat-alat litik tersebut adalah jasper, chert, kuarsit, batuapi, dan metagamping (Jatmiko, dkk., 2012).

\section{Situs Paleolitik Sungai Wai Isal}

Situs Paleolitik Sungai Wai Isal, termasuk wilayah Desa Siatele, Kecamatan Seram Utara, Kabupaten Maluku Tengah. Pengamatan di Sungai Wai Isal dilakukan pada dua titik pengamatan, yaitu titik pengamatan 1 dan titik pengamatan 2 , dengan jarak 430 meter dengan arah tenggara $\left(\mathrm{N} 140^{\circ} \mathrm{E}\right)$. Lokasi pengamatan 1 terletak pada koordinat $02^{\circ} 50^{\prime} 40.9^{\prime \prime}$ Lintang Selatan dan $129^{\circ} 40^{\prime} 31$, 1' Bujur Timur dengan ketinggian $10 \mathrm{~m} \mathrm{dpl}$, dan lokasi pengamatan 2 terletak pada koordinat $02^{\circ} 50^{\prime} 51.5^{\prime \prime}$ Lintang Selatan dan 12940'40.1" Bujur Timur dengan ketinggian $14 \mathrm{~m} \mathrm{dpl}$.

Hasil pengamatan permukaan yang dilakukan di kedua lokasi ini, telah menemukan alat-alat litik berupa serpih (flakes), batu inti (cores) dan serpih dengan retus (retouched flakes) dengan kategori serut samping, serut gerigi, serut cekung dan bilah (pisau). Bahan batuan untuk alat-alat litik tersebut adalah jasper, chert, kuarsit, batuapi, dan metagamping (Jatmiko, dkk., 2012). 
Situs Paleolitik Sungai Wai Salawai

Situs Paleolitik Sungai Wai Salawai, termasuk wilayah Desa Sawai, Kecamatan Seram Utara, Kabupaten Maluku Tengah. Secara geografis titik pengamatan di Sungai Wai Kua berada pada koordinat $02^{\circ} 58^{\prime} 22.1^{\prime \prime}$ Lintang Selatan dan 129'14'14.0" Bujur Timur dengan ketinggian $7 \mathrm{~m}$ dpl.

Situs Paleolitik Sungai Wai Salawai merupakan situs paleolitik yang pertama kali ditemukan di Pulau
Seram pada tahun 1995. Namun pada saat penelitian dilaksanakan, kondisi air sungai sedang meluap atau banjir.

\section{Kabupaten Seram Bagian Timur}

Penelitian di Kabupaten Seram Bagian Timur dilaksanakan di 12 lokasi, yang tersebar di 10 desa (2 kecamatan). Berdasarkan data arkeologis yang berhasil dikumpulkan, diperoleh 7 situs paleolitik, sedangkan 5 lokasi lainnya tidak menunjukkan adanya indikasi aktivitas manusia masa lalu.

Tabel 2. Lokasi Penelitian di Kabupaten Seram Bagian Timur, Provinsi Maluku

\begin{tabular}{|c|c|c|c|}
\hline No & Lokasi & Koordinat & $\begin{array}{l}\text { Ketinggian } \\
\text { (mdpl) }\end{array}$ \\
\hline 1 & $\begin{array}{l}\text { Wai Matakabo, Desa Air Matakabo, Kec. Air } \\
\text { Matakabo, Kab. Seram Timur }\end{array}$ & $\begin{array}{l}03^{\circ} 02^{\prime} 23,1^{\prime \prime L S} \\
130^{\circ} 09^{\prime} 45,4^{\prime \prime} \mathrm{BT}\end{array}$ & 18 \\
\hline 2 & $\begin{array}{l}\text { Wai Pupa, Desa Englas, Kec. Bula, Kab. } \\
\text { Seram Timur }\end{array}$ & $\begin{array}{l}03^{\circ} 02^{\prime} 38,4^{\prime \prime} \mathrm{LS} \\
130^{\circ} 25^{\prime} 42,3^{\prime \prime} \mathrm{BT}\end{array}$ & 9 \\
\hline 3 & $\begin{array}{l}\text { Kali Balipar, Desa Bula Air, Kec. Bula, Kab. } \\
\text { Seram Bagian Timur }\end{array}$ & $\begin{array}{l}03^{\circ} 10^{\prime} 29,4^{\prime \prime} \mathrm{LS} \\
130^{\circ} 33^{\prime} 03,0^{\prime \prime} \mathrm{BT}\end{array}$ & 21 \\
\hline 4 & $\begin{array}{l}\text { Wai Salas, Desa Salas, Kec. Bula, Kab. } \\
\text { Seram Bagian Timur }\end{array}$ & $\begin{array}{l}03^{\circ} 12^{\prime} 48,1 \text { 'LS } \\
130^{\circ} 33^{\prime} 01,5 \text { "BT }\end{array}$ & 26 \\
\hline 5 & $\begin{array}{l}\text { Wai Kola, Desa Salas, Kec. Bula, Kab. } \\
\text { Seram Bagian Timur }\end{array}$ & $\begin{array}{l}03^{\circ} 14^{\prime} 02,3^{\prime \prime} \mathrm{LS} \\
130^{\circ} 33^{\prime} 20,0^{\prime \prime} \mathrm{BT}\end{array}$ & 32 \\
\hline 6 & $\begin{array}{l}\text { Wai Nif, Desa Nif, Kec. Bula, Kab. Seram } \\
\text { Bagian Timur }\end{array}$ & $\begin{array}{l}03^{\circ} 14^{\prime} 45,2^{\prime \prime} \mathrm{LS} \\
130^{\circ} 33^{\prime} 18,5^{\prime \prime} \mathrm{BT}\end{array}$ & 38 \\
\hline 7 & $\begin{array}{l}\text { Wai Mer, Desa Dawang, Kec. Bula, Kab. } \\
\text { Seram Bagian Timur }\end{array}$ & $\begin{array}{l}03^{\circ} 17^{\prime} 13,1 " \mathrm{\prime S} \\
130^{\circ} 35^{\prime} 55,9^{\prime \prime} \mathrm{BT}\end{array}$ & 21 \\
\hline 8 & $\begin{array}{l}\text { Wai Bobi, Unit Pemukiman Transmigrasi, } \\
\text { Kec. Bula Barat, Kab. Seram Bagian Timur }\end{array}$ & $\begin{array}{l}03^{\circ} 02^{\prime} 52,0^{\prime \prime L S} \\
130^{\circ} 16^{\prime} 33,7 \mathrm{BT}\end{array}$ & 20 \\
\hline 9 & $\begin{array}{l}\text { Wai Lola Besar, Desa Bula, Kec. Bula, Kab. } \\
\text { Seram Bagian Timur }\end{array}$ & $\begin{array}{l}03^{\circ} 05^{\prime} 00,4^{\prime \prime} \mathrm{LS} \\
130^{\circ} 27^{\prime} 56,9^{\prime \prime} \mathrm{BT}\end{array}$ & 10 \\
\hline 10 & $\begin{array}{l}\text { Wai Lola Kecil, Desa Bula, Kec. Bula, Kab. } \\
\text { Seram Bagian Timur }\end{array}$ & $\begin{array}{l}03^{\circ} 05^{\prime} 58,5^{\prime \prime} \mathrm{LS} \\
130^{\circ} 28^{\prime} 58,4^{\prime \prime B T}\end{array}$ & 14 \\
\hline 11 & $\begin{array}{l}\text { Kali Mati, Desa Ulae Patolo, Kec. Bula, Kab. } \\
\text { Seram Bagian Timur }\end{array}$ & $\begin{array}{l}03^{\circ} 07^{\prime} 10,5^{\prime \prime} \mathrm{LS} \\
130^{\circ} 30^{\prime} 48,2^{\prime \prime} \mathrm{BT}\end{array}$ & 20 \\
\hline 12 & $\begin{array}{l}\text { Kali Bula Air, Desa Bula Air Patolo, Kec. } \\
\text { Bula, Kab. Seram Bagian Timur }\end{array}$ & $\begin{array}{l}03^{\circ} 07^{\prime} 45,0^{\prime \prime} \mathrm{LS} \\
130^{\circ} 31^{\prime} 24,9^{\prime \prime} \mathrm{BT}\end{array}$ & 12 \\
\hline
\end{tabular}




\section{Situs Paleolitik Sungai Wai Matakabo}

Situs Paleolitik Sungai Wai Matakabo, termasuk wilayah Desa Banggoi-2, Kecamatan Air Matakabo, Kabupaten Seram Bagian Timur. Secara geografis titik pengamatan di Sungai Wai Matakabo berada pada koordinat $03^{\circ} 02^{\prime} 23.1^{\prime \prime}$ Lintang Selatan dan $130^{\circ} 09^{\prime} 45.4^{\prime \prime}$ Bujur Timur dengan ketinggian $18 \mathrm{~m}$ dpl.

Hasil pengamatan permukaan yang dilakukan di lokasi ini, telah menemukan alat-alat litik berupa serpih (flakes), batu inti (cores) dan alat serpih dengan retus (retouched flakes) dengan kategori serut cekung. Bahan batuan untuk alat-alat litik tersebut adalah jasper, chert, kuarsit, batuapi, dan metagamping (Jatmiko, dkk., 2012).

\section{Situs Paleolitik Sungai Wai Pupa}

Situs Paleolitik Sungai Wai Pupa, termasuk wilayah Desa Englas, Kecamatan Bula, Kabupaten Seram Bagian Timur. Secara geografis titik pengamatan di Sungai Wai Pupa berada pada koordinat $03^{\circ} 02^{\prime} 38.4^{\prime \prime}$ Lintang Selatan dan $130^{\circ} 25^{\prime} 42.2$ " Bujur Timur dengan ketinggian 9 meter diatas permukaan air laut (dpl).

Hasil pengamatan permukaan yang dilakukan di lokasi ini, telah menemukan alat-alat litik berupa serpih dengan retus (retouched flake), batu inti (core) dan kapak perimbas (chopper). Bahan batuan untuk alatalat litik tersebut adalah jasper, chert, kuarsit, batuapi, dan metagamping
(Jatmiko, dkk., 2012).

\section{Situs Paleolitik Sungai Wai Balipar}

Situs Paleolitik Sungai Wai Balipar, termasuk wilayah Desa Bula Air, Kecamatan Bula, Kabupaten Seram Bagian Timur. Secara geografis titik pengamatan di Sungai Wai Balipar berada pada koordinat 03010'29.4" Lintang Selatan dan $130^{\circ} 33^{\prime} 03.0^{\prime \prime}$ Bujur Timur dengan ketinggian $21 \mathrm{~m}$ dpl.

Hasil pengamatan permukaan yang dilakukan di lokasi ini, telah menemukan alat-alat litik berupa serut cekung besar. Bahan batuan untuk alatalat litik tersebut adalah jasper, chert, kuarsit, batuapi, dan metagamping (Jatmiko, dkk., 2012).

\section{Situs Paleolitik Sungai Wai Salas}

Situs Paleolitik Sungai Wai Salas, termasuk wilayah Desa Salas, Kecamatan Bula, Kabupaten Seram Bagian Timur. Secara geografis titik pengamatan di Sungai Wai Salas berada pada koordinat 03012'48.1" Lintang Selatan dan $130^{\circ} 33^{\prime} 01.6$ " Bujur Timur dengan ketinggian $26 \mathrm{~m}$ dpl.

Hasil pengamatan permukaan yang dilakukan di lokasi ini, telah menemukan alat-alat litik berupa berupa serpih (flake) dan serut gerigi (denticulated). Bahan batuan untuk alat-alat litik tersebut adalah jasper, chert, kuarsit, batuapi, dan metagamping (Jatmiko, dkk., 2012).

\section{Situs Paleolitik Sungai Wai Kola}

Situs Paleolitik Sungai Wai Kula, termasuk wilayah Desa Salas, 
Kecamatan Bula, Kabupaten Seram Bagian Timur. Secara geografis titik pengamatan di Sungai Wai Kola berada pada koordinat $03^{\circ} 14^{\prime} 02.3^{\prime \prime}$ Lintang Selatan dan $130^{\circ} 33^{\prime} 20.0^{\prime \prime}$ Bujur Timur dengan ketinggian $32 \mathrm{~m}$ dpl.

Hasil pengamatan permukaan yang dilakukan di lokasi ini, telah menemukan alat-alat litik berupa serpih (flakes), alat serpih dengan retus (retouched flakes), kapak perimbas (chopper) dan batu inti (core). Bahan batuan untuk alat-alat litik tersebut adalah jasper, chert, kuarsit, batuapi, dan metagamping (Jatmiko, dkk., 2012).

\section{Situs Paleolitik Sungai Wai Nif}

Situs Paleolitik Sungai Wai Nif, termasuk wilayah Desa Nif, Kecamatan Bula, Kabupaten Seram Bagian Timur. Secara geografis titik pengamatan di Sungai Wai Nif berada pada koordinat $03^{\circ} 14^{\prime} 45.2^{\prime \prime}$ Lintang Selatan dan $130^{\circ} 33^{\prime} 18.5^{\prime \prime}$ Bujur Timur dengan ketinggian $38 \mathrm{~m}$ dpl.

Hasil pengamatan permukaan yang dilakukan di lokasi ini, telah menemukan alat-alat litik berupa serpih (flakes) dan alat serpih dengan retus (retouched flakes) dengan kategori sebagai serut cekung, serut ujung dan serut samping. Bahan batuan untuk alat-alat litik tersebut adalah jasper, chert, kuarsit, batuapi, dan metagamping (Jatmiko, dkk., 2012).

\section{Situs Paleolitik Sungai Wai Mer}

Situs Paleolitik Sungai Wai Mer, termasuk wilayah Desa Dawang,
Kecamatan Bula, Kabupaten Seram Bagian Timur. Secara geografis titik pengamatan di Sungai Wai Mer berada pada koordinat 03017'13.1" Lintang Selatan dan $130^{\circ} 35^{\prime} 55.9^{\prime \prime}$ Bujur Timur dengan ketinggian $21 \mathrm{~m}$ dpl.

Hasil pengamatan permukaan yang dilakukan di lokasi ini, telah menemukan alat-alat litik berupa kapak perimbas (chopper) dan alat serpih dengan retus (retouched flakes) dengan kategori sebagai serut cekung besar dan serut samping. Bahan batuan untuk alat-alat litik tersebut adalah jasper, chert, kuarsit, batuapi, dan metagamping (Jatmiko, dkk., 2012).

\section{Lokasi Survei Lainnya}

Lokasi lainnya di Kabupaten Seram Bagian Timur, yang dikunjungi selama survei berjumlah lima lokasi, namun di lokasi ini tidak ditemukan adanya temuan alat-alat litik yang mengindikasikan adanya aktivitas manusia masa lalu (lokasi nomor 8-12 dalam tabel 2) yaitu, Sungai Wai Bobi, Sungai Wai Lola Besar, Sungai Wai Lola Kecil, Kali Mati, dan Sungai Wai Bula Air.

\section{Kabupaten Seram Bagian Barat}

Penelitian di Kabupaten Seram Bagian Barat dilaksanakan di 15 lokasi, yang tersebar di 12 desa (8 kecamatan). Berdasarkan data arkeologis yang berhasil dikumpulkan, diperoleh dua situs paleolitik, sedangkan 13 lokasi lainnya tidak menunjukkan adanya indikasi aktivitas manusia masa lalu. 
Tabel 3. Lokasi Penelitian di Kabupaten Seram Bagian Barat, Provinsi Maluku

\begin{tabular}{|c|c|c|c|}
\hline No & Lokasi & Koordinat & Ketinggian (mdpl) \\
\hline 1 & $\begin{array}{l}\text { Sungai Wai Kawa, Desa Kawa, Kec. Piru, } \\
\text { Kab. Seram Bagian Barat }\end{array}$ & $\begin{array}{l}02^{\circ} 57^{\prime} 21,8^{\prime \prime L S} \\
128^{\circ} 08^{\prime} 12,8^{\prime \prime B T}\end{array}$ & 8 \\
\hline 2 & $\begin{array}{l}\text { Sungai Wai Eti, Desa Lumoli, Kec. Piru, } \\
\text { Kab. Seram Bagian Barat }\end{array}$ & $\begin{array}{l}03^{\circ} 06^{\prime} 21,6^{\prime \prime} \text { LS } \\
128^{\circ} 13^{\prime} 21,9^{\prime \prime} \mathrm{BT}\end{array}$ & 18 \\
\hline 3 & $\begin{array}{l}\text { Wai Kaputih, Desa Taniwel, Kec. Taniwel, } \\
\text { Kab. Seram Bagian Barat }\end{array}$ & $\begin{array}{l}02^{\circ} 50^{\prime} 43,9^{\prime \prime} \mathrm{LS} \\
128^{\circ} 29^{\prime} 34,7^{\prime \prime} \mathrm{BT}\end{array}$ & 5 \\
\hline 4 & $\begin{array}{l}\text { Wai Yali, Desa Saweli, Kec. Taniwel, Kab. } \\
\text { Seram Bagian Barat }\end{array}$ & $\begin{array}{l}02^{\circ} 51^{\prime} 19,3^{\prime \prime L S} \\
128^{\circ} 33^{\prime} 18,1 " \mathrm{BT}\end{array}$ & 12 \\
\hline 5 & $\begin{array}{l}\text { Wai Teha, Desa Pasinalo, Kec. Taniwel, } \\
\text { Kab. Seram Bagian Barat }\end{array}$ & $\begin{array}{l}02^{\circ} 51^{\prime} 05,7 \mathrm{LS} \\
128^{\circ} 36^{\prime} 24,5^{\prime \prime} \mathrm{BT}\end{array}$ & 10 \\
\hline 6 & $\begin{array}{l}\text { Wai Hanoli, Desa Sohue, Kec. Taniwel, } \\
\text { Kab. Seram Bagian Barat }\end{array}$ & $\begin{array}{l}02^{\circ} 51^{\prime} 12,1 \mathrm{LS} \\
128^{\circ} 38^{\prime} 40,3^{\prime \prime B T}\end{array}$ & 19 \\
\hline 7 & $\begin{array}{l}\text { Wai Kalipana, Desa Taniwel, Kec. Taniwel, } \\
\text { Kab. Seram Bagian Barat }\end{array}$ & $\begin{array}{l}02^{\circ} 52^{\prime} 22,7^{\prime \prime L S} \\
128^{\circ} 24^{\prime} 40,1^{\prime \prime B T}\end{array}$ & 25 \\
\hline 8 & $\begin{array}{l}\text { Wai Kali Sama, Desa Lokolo, Kec. Taniwel, } \\
\text { Kab. Seram Bagian Barat }\end{array}$ & $\begin{array}{l}02^{\circ} 52^{\prime} 08,7 " \mathrm{LS} \\
128^{\circ} 24^{\prime} 40,1^{\prime \prime B T}\end{array}$ & 16 \\
\hline 9 & $\begin{array}{l}\text { Wai Hanua, Desa Murnaten, Kec. Taniwel, } \\
\text { Kab. Seram Bagian Barat }\end{array}$ & $\begin{array}{l}02^{\circ} 51^{\prime} 52,4^{\prime \prime L S} \\
128^{\circ} 21^{\prime} 03,5^{\prime \prime} \mathrm{BT}\end{array}$ & 16 \\
\hline 10 & $\begin{array}{l}\text { Wai Pana, Desa Murnaten, Kec. Taniwel, } \\
\text { Kab. Seram Bagian Barat }\end{array}$ & $\begin{array}{l}02^{\circ} 52^{\prime} 15,0^{\prime \prime L S} \\
128^{\circ} 16^{\prime} 55,4^{\prime \prime} \mathrm{BT}\end{array}$ & 16 \\
\hline 11 & $\begin{array}{l}\text { Wai Aru, Desa Kamal, Kec. Kairatu, Kab. } \\
\text { Seram Bagian Barat }\end{array}$ & $\begin{array}{l}03^{\circ} 12^{\prime} 11,9^{\prime \prime} \text { LS } \\
128^{\circ} 16^{\prime} 37,6^{\prime \prime} \text { BT }\end{array}$ & 15 \\
\hline 12 & $\begin{array}{l}\text { Wai Kamal Desa Kamal Kec. Kairatu, Kab. } \\
\text { Seram Bagian Barat }\end{array}$ & $\begin{array}{l}03^{\circ} 13^{\prime} 20,8^{\prime \prime} \text { LS } \\
128^{\circ} 17^{\prime} 26,2^{\prime \prime} \text { BT }\end{array}$ & 10 \\
\hline 13 & $\begin{array}{l}\text { Wai Kawaninu Desa Waisamu Kec. Kairatu } \\
\text { Kab. Seram Bagian Barat }\end{array}$ & $\begin{array}{l}03^{\circ} 15^{\prime} 41,5^{\prime \prime} \text { LS } \\
128^{\circ} 18^{\prime} 25,3^{\prime \prime} \text { BT }\end{array}$ & 12 \\
\hline 14 & $\begin{array}{l}\text { Air Wapa Desa Kairatu Kec. Kairatu, Kab. } \\
\text { Seram Bagian Barat }\end{array}$ & $\begin{array}{l}03^{\circ} 20^{\prime} 23,9^{\prime \prime} \text { LS } \\
128^{\circ} 21^{\prime} 49,8^{\prime \prime} \text { BT }\end{array}$ & 11 \\
\hline 15 & $\begin{array}{l}\text { Wai Selopai Desa Seriawan Kec. Kairatu } \\
\text { Kab. Seram Bagian Barat }\end{array}$ & $\begin{array}{l}03^{\circ} 24^{\prime} 09,4^{\prime \prime} \text { LS } \\
128^{\circ} 23^{\prime} 57,3^{\prime \prime} \text { BT }\end{array}$ & 12 \\
\hline
\end{tabular}

\section{Situs Paleolitik Sungai Wai Kawa}

Pengamatan dilakukan di aliran Sungai Wai Kawa yang termasuk wilayah Desa Kawa, Kecamatan Piru, Kabupaten Seram Bagian Barat. Secara geografis titik pengamatan di Sungai Wai Kawa berada pada koordinat $02^{\circ} 57^{\prime} 21.8^{\prime \prime}$ Lintang Selatan dan $128^{\circ} 08^{\prime} 12.8^{\prime \prime}$ Bujur Timur dengan ketinggian $8 \mathrm{~m}$ dpl.
Hasil pengamatan permukaan yang dilakukan di lokasi ini, telah menemukan alat-alat litik berupa serpih (flske) dan batu inti (cores). Bahan batuan untuk alat-alat litik tersebut adalah jasper, chert, kuarsit, batuapi, dan metagamping (Jatmiko, dkk., 2012). 


\section{Situs Paleolitik Sungai Wai Eti}

Pengamatan dilakukan di aliran Sungai Wai Eti yang termasuk wilayah Desa Lumoli, Kecamatan Piru, Kabupaten Seram Bagian Barat. Secara geografis titik pengamatan di Sungai Wai Eti berada pada koordinat $03^{\circ} 06^{\prime}$ 21.6" Lintang Selatan dan $128^{\circ}$ 13' 21.9" Bujur Timur dengan ketinggian $18 \mathrm{~m}$ dpl.

Hasil pengamatan permukaan yang dilakukan di lokasi ini, telah menemukan alat-alat litik berupa serpih besar (big flakes). Bahan batuan untuk alat-alat litik tersebut adalah jasper, chert, kuarsit, batuapi, dan metagamping (Jatmiko, dkk., 2012).

\section{Lokasi Survei Lainnya}

Lokasi lainnya di Kabupaten Seram Bagian Barat, yang dikunjungi selama survei berjumlah 13 lokasi, namun di lokasi ini tidak ditemukan adanya temuan alat-alat litik yang mengindikasikan adanya aktivitas manusia masa lalu (lokasi nomor 3-15 dalam tabel 3) yaitu, Kali Putih, Sungai Wai Yali, Sungai Wai Teha, Sungai Wai Hanoli, Kali Pama, Kali Sama, Kali Hanua, Sungai Wai Pana, Sungai Wai Aru, Kali Kamal, Sungai Wai Kawaninu, Sungai Air Wapa, dan Sungai Air Selopai.

\section{Analisis Petrologi Alat-Alat Litik}

Hasil industri pendukung budaya paleolitik Pulau Seram, adalah alatalat litik. Alat-alat litik yang ditemukan tersebut, berdasarkan atas hasilanalisis petrologi, ternyata mereka memilih batuan-batuan yang mempunyai sifatsifat khusus antara lain, struktur batuan yang kompak (massive), sifat mudah terbelah (breakability) yang baik, tidak mempunyai pecahan (fracture), mempunyai kekerasan (hardness) yang tinggi, kesamaan mineral (homogenity), dan beberapa sifat fisik lain yang mendukung (Intan, 1999).

Klasifikasi petrologi dilakukan terhadap semua alat-alat litik yang ditemukan selama penelitian. Tujuan dari klasifikasi petrologi adalah untuk mengetahui jenis batuan yang dimanfaatkan sebagai alat-alat litik, yang dilakukan secara megaskopis. Hasil klasifikasi tersebut, maka batuan yang terpilih sebagai alat litik di Pulau Seram adalah jasper, chert, metagamping, batuapi, dan kuarsit, sebagai berikut:

a Jasper, berdasarkan klasifikasi petrologi, jasper termasuk batuan sedimen yang memberikan kenampakan warna segar merah hati dan lapuk berwarna merah kehitaman. Bertekstur non klastik, dengan struktur tidak berlapis (non stratified). Komposisi mineral adalah hematit. Berdasarkan atas genesanya, maka jasper termasuk pada batuan sedimen kimia (Huang, 1962).

b Chert, berdasarkan klasifikasi petrologi, chert termasuk batuan sedimen yang memberikan kenampakan warna segar putih kuning keabu-abuan dan lapuk berwarna abu-abu pudar kehitaman. Bertekstur non klastik, 
dengan struktur tidak berlapis (non stratified). Komposisi mineral adalah silikat atau opal. Berdasarkan atas genesanya, maka chert termasuk pada batuan sedimen kimia (Huang, 1962).

c Metagamping, berdasarkan klasifikasi petrologi, metagamping termasuk batuan metamorf yang memberikan kenampakan warna segar putih keabu-abuan dan lapuk berwarna putih kusam. Bertekstur kristaloblastik, dengan struktur kataklastik. Komposisi mineral adalah Kalsium karbonat (CaCO3) (Huang, 1962).

d Batuapi, berdasarkan klasifikasi petrologi, batuapi (flint) termasuk batuan sedimen yang memberikan kenampakan warna segar putih kekuningan dan lapuk berwarna putih kotor. Bertekstur non klastik, dengan struktur tidak berlapis (non stratified). Komposisi mineral adalah cryptocrystalline kalsedon dan kuarsa. Berdasarkan atas genesanya, maka batuapi termasuk pada batuan sedimen kimia (Huang, 1962).

e Kuarsit, berdasarkan klasifikasi petrologi, kuarsit termasuk batuan metamorf yang memberikan kenampakan warna segar putih kecoklatan dan lapuk berwarna coklat kelabu. Bertekstur granoblastik, dengan struktur non foliasi Komposisi mineral di dominasi oleh kuarsa. Klasifikasi berdasarkan atas struktur, tekstur, dan komposisi mineralnya, maka batuan kuarsit termasuk pada batuan metamorf unfoliasi (Huang, 1962).

Berdasarkan hasil penelitian yang dilakukan di Pulau Seram, telah berhasil di data sejumlah situs yang mengandung sumberdaya paleolitik. Sebaran tinggalan budaya paleolitik di Pulau Seram tersebut, sebagian besar ditemukan di Kabupaten Seram Bagian Timur, menyusul Kabupaten Maluku Tengah sedangkan di Kabupaten Seram Bagian Barat lebih sedikit. Hal ini terlihat bahwa dari 32 lokasi pengamatan, maka Kabupaten Seram Bagian Timur ditemukan tujuh situs paleolitik, Kabupaten Maluku Tengah, ditemukan lima situs paleolitik, dan Kabupaten Seram Bagian Barat ditemukan dua situs paleolitik.

Situs paleolitik Pulau Seram terletak pada bentang alam yang termasuk dalam Satuan Morfologi Dataran, dengan prosentase kemiringan lereng antara 0-2\%. Dari segi morfologi, Pulau Seram memperlihatkan ketinggian dari arah barat ke timur, demikian pula dilihat dari arah selatan (lebih tinggi) ke utara (lebih landai) (lihat Peta 4). Di bagian timur, rata-rata ketinggian situs antara 7-45 m dpl, di bagian tengah rata-rata ketinggian situs antra 9-38 m dpl, dan di bagian barat rata-rata ketinggian situs antara 8-18 dpl. Dari penngamatan ketinggian situs, maka wilayah bagian timur, merupakan daerah datar yang luas, dari arah pantai ke arah pegunungan, yang dibuktikan masih 
ditemukannya situs dengan ketinggian 38 m dpl (Situs Paleolitik Sungai Wai Nif), bila dibandingkan dengan bagian tengah dan barat.

Pada Budaya tertua (paleolitik) kehidupan dan pemanfaatan lahan terpusat dibentang alam terbuka, yaitu di sekitar dan sepanjang aliran sungai (Simanjuntak, 2014:3-11), atau yang dikenal dengan istilah Situs Terbuka (open-site). Pernyataan ini, sesuai dengan morfologi Pulau Seram, dimana situs-situs Paleolitik di Pulau

\section{PENUTUP}

Bentang alam wilayah penelitian terdiri atas empat satuan morfologi, yaitu, Satuan morfologi dataran, Satuan morfologi bergelombang lemah, Satuan morfologi bergelombang kuat, dan Satuan morfologi karst. Pola aliran permukaan (surface drainage pattern) sungai-sungai ke arah utara dan mengikuti bentuk bentang alam lokasi penelitian. Sungai-sungai tersebut termasuk pada kelompok sungai yang berstadia Sungai Dewasa-Tua (oldmature river stadium) dan Sungai Tua (old stadium), Sungai Periodik/ Permanen dan Sungai Episodik/ Intermittent.

Batuan penyusun wilayah Pulau Seram dan sekitarnya, terdiri dari batupasir (berumur Trias Akhir Jura), batugamping (berumur Trias Akhir - Jura), napal (berumur Oligosen Akhir - Miosen Tengah), andesit (diperkirakan berumur Miosen Akhir), tufa (diperkirakan berumur Miosen Akhir), sekis (berumur Miosen Akhir),
Seram Bagian Utara, lebih banyak ditemukan di bagian Timur (Kabupaten Seram Bagian Timur) bila dibandingkan dengan di bagian tengah (Kabupaten Maluku Tengah), dan bagian barat (Kabupaten Seram Bagian Barat). Sedangkan bahan baku alat-alat litik, banyak tersedia di bagian tengah Pulau Seram (Kabupaten Maluku Tengah), lalu disebarkan ke arah barat dan ke arah timur yang mempunyai relief datar.

breksi volkanik (berumur Pliosen), batugamping terumbu (diperkirakan berumur Plistosen Atas-Holosen), konglomerat (berumur Plistosen - Holosen), dan aluvial (berumur Holosen). Struktur geologi yang melewati wilayah penelitian dan sekitarnya adalah Patahan (fault) dari jenis sesar naik (thrust fault), dan sesar geser (strike slip fault), sedangkan Lipatan (fold) dari jenis antiklin (anticline).

Penelitian di wilayah Pulau Seram bagian utara (tiga kabupaten) yang telah dilakukan di 32 lokasi, telah berhasil menemukan 14 situs paleolitik. Dari analisis petrologi, maka batuan yang dimanfaatkan sebagai alat-alat litik adalah jasper, chert, metagamping, batuapi, dan kuarsit. Diharapkan, tulisan yang berupa data dasar ini, dapat digunakan sebagai acuan dalam penelitian-penelitian lingkungan di wilayah Maluku, khususnya di Pulau Seram. 


\section{DAFTAR PUSTAKA}

Army Service Map. 1968. Peta Topografi Sheet 52 (Ambon) Series 1301 Edition 3-AMS Word (Asia) 1:1.000.000.

Bemmelen, R.W. van. 1949. The Geology of Indonesia IA. The Hague: Martinus Nijhoff.

Billing, M. P. 1972. Structural Geology. Prentice-Hall, Inc. Englewood Cliggs, New Jersey.

Desaunettes, J R. 1977. "Catalogue of Landforms for Indonesia: Examples of a Physiographic Approach to Land Evaluation for Agricultural Development". Unpublished. Bogor: Trust Fund of the Government of Indonesia Food and Agriculture Organization.

Gafoer S., K. Suwitodirdjo, Suharsono. 1993. Geologi Lembar Bula dan Watubela, Maluku. Bandung: Pusat Penelitian dan Pengembangan Geologi.

Hadiwisastra, Sapri. 1999. "Temuan Alat Batu Paleolitik dari Daerah Sawai, Seram Tengah, Maluku”. PIA VII, Jilid-7. Jakarta: Puslit Arkenas. HIm. 85 - 90.

Huang, Walter T. 1962. Petrology. McGraw-Hill Book Company.

Intan S. Fadhlan, M. 1999. "Aspek-Aspek Geologi yang Berpengaruh di Situs Gua Braholo, Dusun Semugih, Kel. Semugih, Kec. Rongkop, Kab. Gunung Kidul, Prov. D.I. Yogyakarta". LPA Bidang Arkeometri. Jakarta: Puslit Arkenas.

Jarvis, A., H.I. Reuter, A. Nelson, dan E. Guevara. 2008. Hole-filled seamless SRTM data V4. Center for Tropical Agliculture (CIAT).

Jatmiko, Intan S. Fadhlan M., Ririmase Marlon, Simanjuntak Harry T. 2012. "Penelitian (Eksplorasi) Sumberdaya Budaya Paleolitik di Seram Bagian Utara, Provinsi Maluku". LPA, Pusat Penelitian dan Pengembangan Arkeologi Nasional.

Kemp, G. 1992. "The Manusela Formation an Example of a Jurassic Carbonate Unit of the Australian Plate from Seram, Eastern Indonesia. In: Carbonate Rocks and Reservoirs of Indonesia: a Core Workshop". Indonesian Petroleum Association. p.11.1-33.

Kemp, G. and Mogg, W. 1992."A Reappraisal of the Geology, Tectonics, and Prospectivity of Seram Island, Eastern Indonesia". Proceedings, Indonesian Petroleum Association, 21st Annual Convention. p. 521-551.

Kemp, G., Mogg, W. and Barraclough, R. 1995. Exploration of the Mesozoic in the Seram PSC, eastern Indonesia: Recent Developments in Geological Knowledge. Pertamina Training Center, Symposium and Workshop on the Mesozoic in the eastern part of Indonesia. (unpublished).

Kusuma S. Dendi, Kholik Muhammad, Rosli R. Liliek. 2012. "Penelitian Geofisika Terpadu Daerah Panas Bumi Tehoru, Pulau Seram, Kabupaten Maluku Tengah, Provinsi Maluku. Pusat Sumber Daya Geologi”. Prosiding Hasil Kegiatan Pusat Sumber Daya Geologi Tahun 2011. Buku 1: Bidang Energi. HIm. 591-601. 
Lobeck A.K. 1939. Geomorphology, An Introduction To The Study of Landscape. New York and London: Mc Graw Hill Book Company Inc.

Simanjuntak, Harry Truman. 2004. "Gunung Sewu: Sejarah Hunian Panjang” dalam Prasejarah Gunung Sewu. Editor: Truman Simanjuntak, Retno Handini, Bagyo Prasetyo. HIm. 3-11.

Tjokrosapoetro S., E. Rusmana dan A. Achdan. 1993a. Peta Geologi Lembar Ambon, Maluku. Bandung: Pusat Penelitian dan Pengembangan Geologi.

Tjokrosapoetro S., A. Achdan, K. Suwitodirdjo, E. Rusmana dan H. Z. Abidin. 1993b. Peta Geologi Lembar Masohi. Bandung: Pusat Penelitian dan Pengembangan Geologi.

Thornbury, W.D.1964. Principle of Geomorphology. New York, London: John Wiley and Sons, inc.

Todd, D.K.1980. Groundwater Hidrology. New York: John Wiley \& Sons Inc. 